\title{
Social Capital and Social Capacity in Rural Ecotourism Development
}

\author{
Iwan Nugroho ${ }^{1}$, Rita Hanafie ${ }^{1}$, Purnawan Dwikora Negara ${ }^{2}$, Sudiyono ${ }^{3}$ and Hefifa Rhesa Yuniar \\ ${ }^{1}$ Agribusiness Department, Widyagama University of Malang, Indonesia \\ ${ }^{2}$ Law Department, Widyagama University of Malang, Indonesia \\ ${ }^{3}$ Food Technology Department, Widyagama University of Malang, Indonesia \\ ${ }^{4}$ University Library, Widyagama University of Malang, Indonesia
}

Received: $2020-05-26$

Accepted: 2021-04-19

Keywords:

rural development;

ecotourism;

Bromo;

social capital;

social capacity

Correspondent email:

iwanuwg@widyagama.ac.id

\begin{abstract}
The participation of rural people in ecotourism activity remains the question, whether they genuinely carry the vision of conservation or are forced to engage in meeting economic needs only. This question is fundamental for building better participation and management of ecotourism in rural areas. The research aims to discuss social capital and social capacities to empower ecotourism in rural areas. The study was carried out in the villages of Ngadas and Gombengsari using a survey approach, and employing descriptive and path analysis methods. The results show that social capital for managing ecotourism services demonstrated the functioning of institutions, networking capabilities, monitoring, evaluation, and innovation. Social capacity is related to the regulation of institutional, social, economic, and environmental resources. Social capacity was found more substantial in Gombengsari than Ngadas village. The research is expected to strengthen the study of social capital as a stock/sink and its relationship with sustainability.
\end{abstract}

92021 by the authors. Licensee Indonesian Journal of Geography, Indonesia.

This article is an open access article distributed under the terms and conditions of the Creative Commons

Attribution(CC BY NC) licensehttps://creativecommons.org/licenses/by-nc/4.0/.

\section{Introduction}

The development of economic activities in rural areas shows a shift from agricultural activities to sustainable tourism (Jeyacheya \& Hampton, 2020; Nugroho, Negara, \& Yuniar, 2018). However, implementing sustainable tourism has always been a challenge. The complexity in sustainable tourism is genuine, covering social, economic, and environmental aspects. These aspects must be managed optimally and sustainably (Volkmer \& Pedrozo, 2019).

Sustainable tourism has developed in rural areas across the region, such as agrotourism, cultural tourism, or heritage tourism. One of the activities that can accommodate sustainable tourism in rural areas is ecotourism. Ecotourism is responsible tourism that shows sustainable nature tourism while incorporating rural and cultural elements (Wood, 2002). In Indonesia, ecotourism services have developed in regions and rural areas, or around national park areas. Availability and access, such as transportation, accommodation, and tourism service facilities, have a significant contribution to realizing the progress (Handriana \& Ambara, 2016).

Social capacity building is an essential component in the sustainability of tourism resource management (Schwaninger, 2018). As such, social capacity is a consequence of social capital. Social capacity describes flows/ consequences of social capital during a certain period. It is defined as the growth or development of each characterized level of human or social integration within a certain spatial range, determined by interaction activities within an individual and between individuals or groups of individuals within a certain period (Mauerhofer, 2013).
In principle, institutional capacity reflects the conditions of social capital, which can be characterized by building trust, collectivism, and authority (Yolles, 2018a). Social capacity is an instrument of social aspects that can organize complexity, through regulation, cooperation, and empowerment of the parties involved. Increased local capacity indicates an improved situation using ecotourism awareness and knowledge, empowerment and participation, local leadership, organizations (Rasid, Mustafa, Suradin, \& Hassan, 2012), and entrepreneurship and innovation (Purnomowati, Nugroho, \& Negara, 2012).

Institutional capacity needs to be developed in the management of local people-based tourism services. The life of local people has functional values from social and environmental aspects. Local people need to develop their potential, and be encouraged to be involved significantly in tourism activities (Mendoza-Ramos \& Zeppel, 2009; Rasid et al., 2012; Scheyvens, 1999; Solár, Janiga, \& Markuljaková, 2016). They are required to collaborate with other parties, develop innovations to increase added value from tourism activities. Local policies are designed effectively to empower communities, promote tourism and conservation, and environmental aesthetics (Lopez \& Bhaktikul, 2018; Mursid, Suharno, \& Priatna, 2018).

Social capacity flows from social capital, which is a stock or source. The conception of social capital as a stock provides a medium for resource allocation mechanisms, including social, environmental, and economic aspects (Mauerhofer, $2008,2013)$. Social capacity can grow in line with the growth of the social capital stock. 
Social capital is a concept that refers to social ties (Putnam, 2001) to produce community empowerment and participation, accompanied by commitment and optimal life performance (DeFilippis, 2001; Fukuyama, 2000). Social capital is the result of the interaction of norms, traditions, religion, historical experience (Fukuyama, 2001). Social capital forms an institution that sustains certain norms, which binds various interests (networks), builds trust and motivation for contributing the benefits of managing a resource (Sunkar, Meilani, Rahayuningsih, \& Muntasib, 2016).

The conception of social capital provides a mechanism for allocating a resource. Resource management works optimally due to the functioning of the factors of norms, cooperation, trust, and social cohesiveness (Grootaert, Narayan, Jones, \& Woolcock, 2004). Social capital is the foundation of society to solve their problems and is a strength for society to be independent and defend themselves from external changes. The more social capital the people have, the stronger the community will be (Amornsiriphong, Piemyat, \& Charoenrat, 2012).

The implementation of social capital in tourism development has been widely studied. Nunkoo, Ramkissoon, \& Gursoy (2012) argue that the role of institutions, authority, and trust among local people become a determining factor in developing tourism service businesses. Bennett \& Dearden (2014) sees the importance of mutual trust between local people and national parks in the context of sustainable management of coastal resources. Negative perceptions develop because there is no trust, about how the roles of the parties and what can be contributed. Trust can generate positive interpersonal relationships and enhance collective action to develop tourism (Sunkar et al., 2016).

Baksh, Soemarno, Hakim, \& Nugroho (2013) argues that social capital would stimulate the management and development of ecotourism. Bennett \& Dearden (2014) states that the performance of institutions in tourism services can work optimally when the people show empowerment and interpersonal trust between them. The social capital of the people of the villages of Candirejo (Magelang) and Rajegwesi (Meru Betiri National Park) (Nugroho \& Negara, 2014), shows the success of building a tourism village. Meanwhile, the social capital of Ngadas village has not been optimally developed (Purnomowati et al., 2012). Social capital has developed positively in the village of Gombengsari (Hernanda, Mindarti, \& Riyanto, 2018), thus enhancing ecotourism activity based on coffee and etawa goats (Kelurahan Gombengsari, 2018). The lives of local people have functional values in terms of social and environmental aspects. The local people need to develop their potential and capacity to engage in tourism activities (Mendoza-Ramos \& Zeppel, 2009; Rasid et al., 2012; Solár et al., 2016).

Ngadas Village in Malang Regency and Gombengsari Village in Banyuwangi Regency are villages that are developing ecotourism activities. The rural people work in the farmland and have also often welcomed tourists in the village. Ngadas village tourism developed as the influence of the main tourist destinations of Bromo mount. Meanwhile, Gombengsari tourism increased as an impact of the tourist destinations of the Ijen crater and Bali. Those villages carry out ecotourism activities with their different characters in economic, social, and environmental aspects as well.

However, the participation of local people in ecotourism services remains the question, whether they genuinely carry the vision of conservation or are forced to engage in meeting economic needs only. This is confirmed through studies (Jeyacheya \& Hampton, 2020; Kim, Xie, \& Cirella, 2019) in developing countries. This question is fundamental to the formulation of ecotourism development policy concepts or to building better participation and management of ecotourism in rural areas.

Social capital and social capacity need to grow in the management of tourism services based on local people's life. This study also wants to explore further both social capital and social capacity as outlined (Mauerhofer, 2008, 2013; Volkmer \& Pedrozo, 2019), where previous studies did not distinguish in detail. Social capacity provides direction for planning sustainable tourism resource management. In this study, social capital is addressed to the description of norms, trusts, networks, and participation. While social capacity is approached by regulating the relationship of social, environmental, and economic aspects in the management of tourism resources. The arrangement of social, environmental, or economic aspects can form a management model, show the most critical components, and provide alternative decision making.

This study aims to discuss the role of social capital and its implementation in social capacities to empower ecotourism activity in rural areas.

\section{Method}

The study was conducted in a rural tourism area, Ngadas Village, Poncokusumo District, Malang Regency, and Gombengsari Village, Kalipuro district, Banyuwangi Regency. Ngadas Village is located within the Bromo Tengger Semeru National Park area. This village receives tourist visits who are going to the national park area. Gombengsari is a village that is famous for having coffee and Etawa goats

This research used a survey approach to explore qualitative and quantitative data. Interviews were employed with respondents from community leaders, village tourism managers, youth leaders, farmers, and tour operators. Secondary data were obtained from village data and village development documents, such as demographic overview and planning document.

The analysis method comprises two parts to meet the research objectives. First, survey methods explore qualitative and descriptive data about social capital. In-depth interviews on four key persons in each village were to explore data on norms, trusts, networks, and participation data. They are the village head, the manager of the village tourism institution, the tourism actor, and the youth figure, and are involved in developing ecotourism activities in the village.

The second analysis, variable and indicator related to social capacity acquired from the survey to a total of 40 and 50 respondents who were randomly selected from Ngadas and Gombengsari villages, respectively. The response of perceptions presented in Table 1. Respondents' perceptions are expressed on the ordinal scale (Likert). Questions provide five answer choices, including strongly agree (5), agree (4), moderate (3), disagree (2), and strongly disagree (1).The analytical method concerning the second research objective uses path modeling (partly least square, PLS), processed using the SmartPLS 3.2.6 software application. PLS path modeling has reliability, such as structural equation modeling (SEM) to analyze the relationship between latent variables 
Table 1. Variable and indicator related to social capacity

\begin{tabular}{|c|c|}
\hline Variable & Indicator \\
\hline \multirow[t]{4}{*}{ Ecotourism (Et) } & 1. Income rose from tourism businesses (Et1) \\
\hline & 2. Saving rose from tourism businesses (Et2) \\
\hline & 3. Welfare rose from tourism businesses (Et3) \\
\hline & 4. Children's education is more guaranteed with tourism businesses (Et4) \\
\hline \multirow[t]{6}{*}{ Social (S) } & 1. Communication between citizens is getting better $(\mathrm{S} 1)$ \\
\hline & 2. Citizens are increasingly tolerant and open (S2) \\
\hline & 3. The security in the village area is increasingly conducive (S3) \\
\hline & 4. Citizen participation in meetings is getting higher (S4) \\
\hline & 5. Conflict of interest (S5) \\
\hline & 6. Hospitality to tourists is getting better (S6) \\
\hline \multirow[t]{4}{*}{ Economic (E) } & 1. Development of tourism infrastructure (E1) \\
\hline & 2. Increased village economy (E2) \\
\hline & 3. Tourism economic cooperation (E3) \\
\hline & 4. Citizen participation in economic development (E4) \\
\hline \multirow[t]{5}{*}{ Environment (En) } & 1. Concern for environmental conservation (En1) \\
\hline & 2. Villages are getting cleaner (En2) \\
\hline & 3. More protected from landslides (En3) \\
\hline & 4. Availability of trash bins (En4) \\
\hline & 5. Availability of agricultural plant seeds (En5) \\
\hline \multirow[t]{5}{*}{ The institution (I) } & 1. Evaluation of tourism businesses (I1) \\
\hline & 2. The role of leadership in advancing business (I2) \\
\hline & 3. The organization is committed to advancing business (I3) \\
\hline & 4. Transparency in organizational financial management (I4) \\
\hline & 5. The organization is committed to solving problems (I5) \\
\hline
\end{tabular}

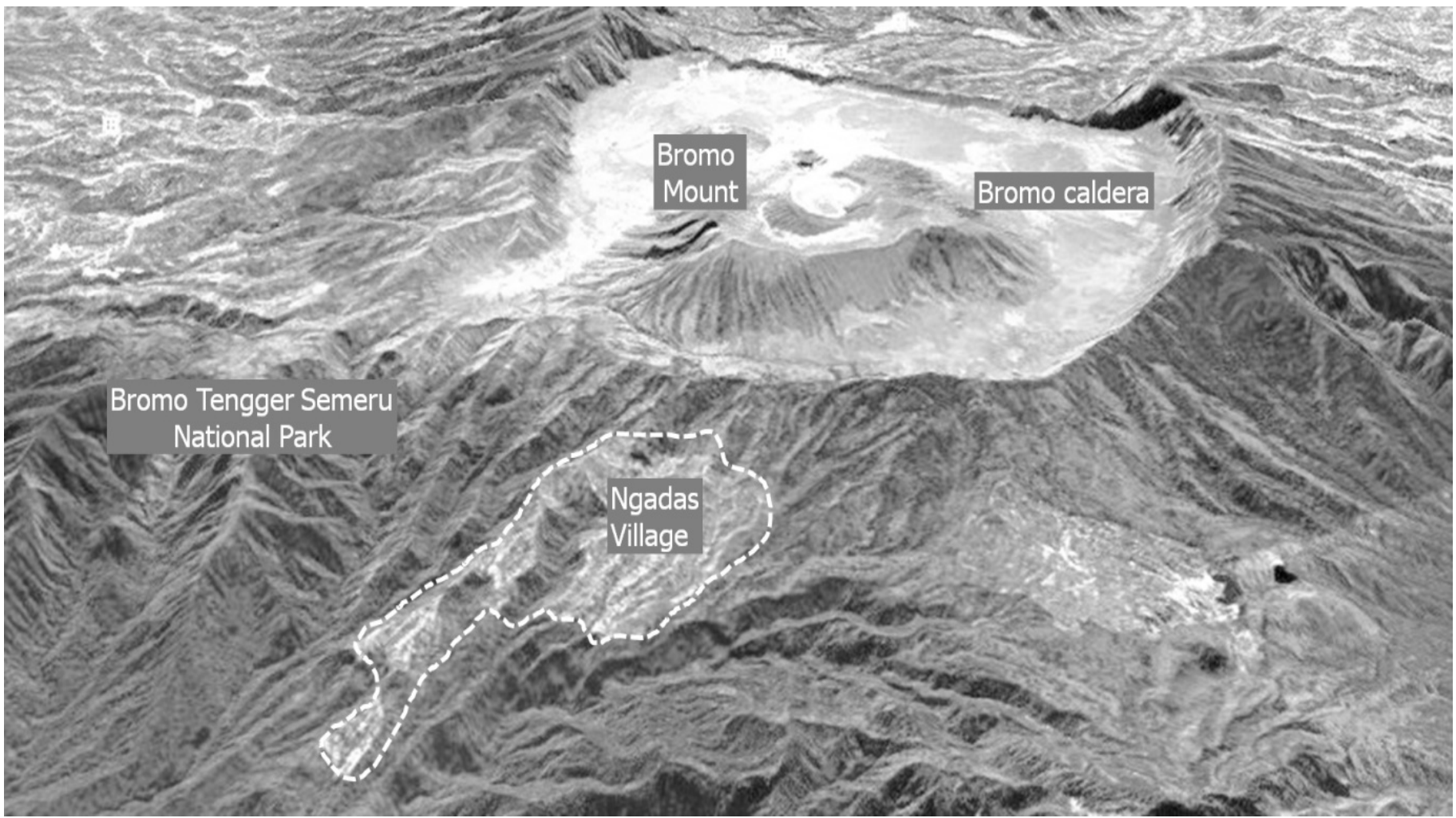

Figure 1. Ngadas village stting. Source: Adopted from (Desa Ngadas, 2018). 
Table 2. Tourism Products and Services in Ngadas village

\begin{tabular}{|c|c|c|}
\hline Tourism products/ objects/facilities & Attractions & Managed by \\
\hline $\begin{array}{l}\text { The natural and cultural landscape } \\
\text { around Bromo and Semeru mount }\end{array}$ & $\begin{array}{l}\text { Sand sea, Mount Bromo, Penanjakan, and other objects, } \\
\text { the Kasodo tradition }\end{array}$ & $\begin{array}{l}\text { Individual, Ladewi (village } \\
\text { tourism management agency) }\end{array}$ \\
\hline $\begin{array}{l}\text { Karo ceremony, and other traditional } \\
\text { rituals }\end{array}$ & Traditions respect ancestors and confusion & $\begin{array}{l}\text { Shamans and village govern- } \\
\text { ment }\end{array}$ \\
\hline Offroad car rental (53 jeeps) & $\begin{array}{l}\text { Enjoy the natural scenery around Bromo and Semeru } \\
\text { mount }\end{array}$ & Individual \\
\hline Homestay (56 houses) & Stay overnight, get to know Tengger's socio-cultural life & Individual \\
\hline Rent a motorcycle & Transportation services to tourist sites & Individual \\
\hline
\end{tabular}

Table 3. The Area of Coffee Plants in Gombengsari

\begin{tabular}{lcl}
\hline Hamlet & Area size (ha) & Coffee land type \\
\hline Gombeng & 50 & Farmer coffee \\
Kacangan Asri & 70 & Farmer coffee \\
Suko & 120 & Farmer coffee \\
Lerek & 131 & Farmer coffee \\
Kaliklatak & 1013 & Coffee plantation company \\
\hline
\end{tabular}

Source: (Kelurahan Gombengsari, 2018)

and allows the use of smaller sample sizes (minimum 30 ). The model is constituted hypothetically using the conception and relationship between variables adapted from (Schwaninger, 2018; Yolles, 2018b, 2018a).

\section{Results and Discussion}

General Description of Research Areas

1. Ngadas village

Ngadas village is administratively under the authority region of Poncokusumo District, Malang Regency. Ngadas is one of the villages that are in the Bromo Tengger Semeru National Park (BTSNP) area. The geographical position is at coordinates $-7.981614,112.909946$ at an altitude of 2000 to $2200 \mathrm{~m}$ above sea level. On average, daily temperature ranges from $17^{\circ} \mathrm{C}-22^{\circ} \mathrm{C}$. The physiography of the village is hilly and mountainous, a place just west of the slopes of the Bromo caldera. The view of the village shows the beauty of the panoramic mountain landscape and is often covered with a thin mist, which causes this village to always beautiful, quiet, and calm. The topographic position of Ngadas village is depicted in Figure 1.

The population of the village of Ngadas was 1896 people or 496 households. Villagers work primarily as farmers, cultivating food crops, and horticulture in dryland management. The condition of agricultural land is steeply sloped so that it is vulnerable to surface runoff and conservation threats. The population embraces Javanese Buddhism by 50 percent, Islam 40 percent, and Hindu 10 percent. They carry out the Tengger cultural traditions in various aspects of life (Purnomo, In Oktaviani, \& Nugroho, 2018). The popular Tengger tradition is the Kasodo and Karo ritual, which has the meaning to remember and uphold the values of its ancestral heritage.
The natural beauty of Bromo and the cultural traditions of Tengger are the main tourist attractions (Table 2). Tourists can stay in the Ngadas village and enjoying the hospitality typical of the Tengger tribe. In the village, 56 homestays are ready to serve the needs of tourists. Tourists will be pleased to enjoy the warmth of the heating furnace in the kitchen while chatting with the homestay owner. The hospitality and family feel of Tengger people always gives a potential impression to tourists. The people also provide jeep or motorcycle transportation for tourists who want to get around in the national park area. They also offer processed products from local fruits or food crops.

\section{Gombengsari village}

Gombengsari village is located in the Kalipuro district, Banyuwangi Regency. Gombengsari Village is about 12 kilometers north of Banyuwangi City. Gombengsari Village is a plateau area, in the position of around $650 \mathrm{~m}$ above sea level, with undulating physiography and hills. Temperatures range from $23-30^{\circ} \mathrm{C}$, with an average rainfall of $2,088 \mathrm{~mm}$. Gombengsari has an area of 19.95 thousand hectares, with land use includes settlements of 1,230 ha, paddy fields 55 ha, plantations/agriculture 1998 ha, forests 16,630 ha, and others 40 ha (Kelurahan Gombengsari, 2018). The setting of Gombangsari village is shown in Fig. 2. Gombengsari village is divided into five hamlets, consisting of Gombeng, Kacangan, Lerek, Suko and Kaliklatak (Table 3). In 2018 the population numbered 2,853 families or 6,974 people (Kelurahan Gombengsari, 2018). Most people are Muslim, featuring ethnic Madurese and Javanese backgrounds. The main livelihoods are to cultivate plantation crops of coffee, coconut, clove, bamboo, banana, rambutan, durian, mangosteen, and langsat. Coffee is the primary commodity of Gombengsari. In the Kaliklatak hamlet, a private company 


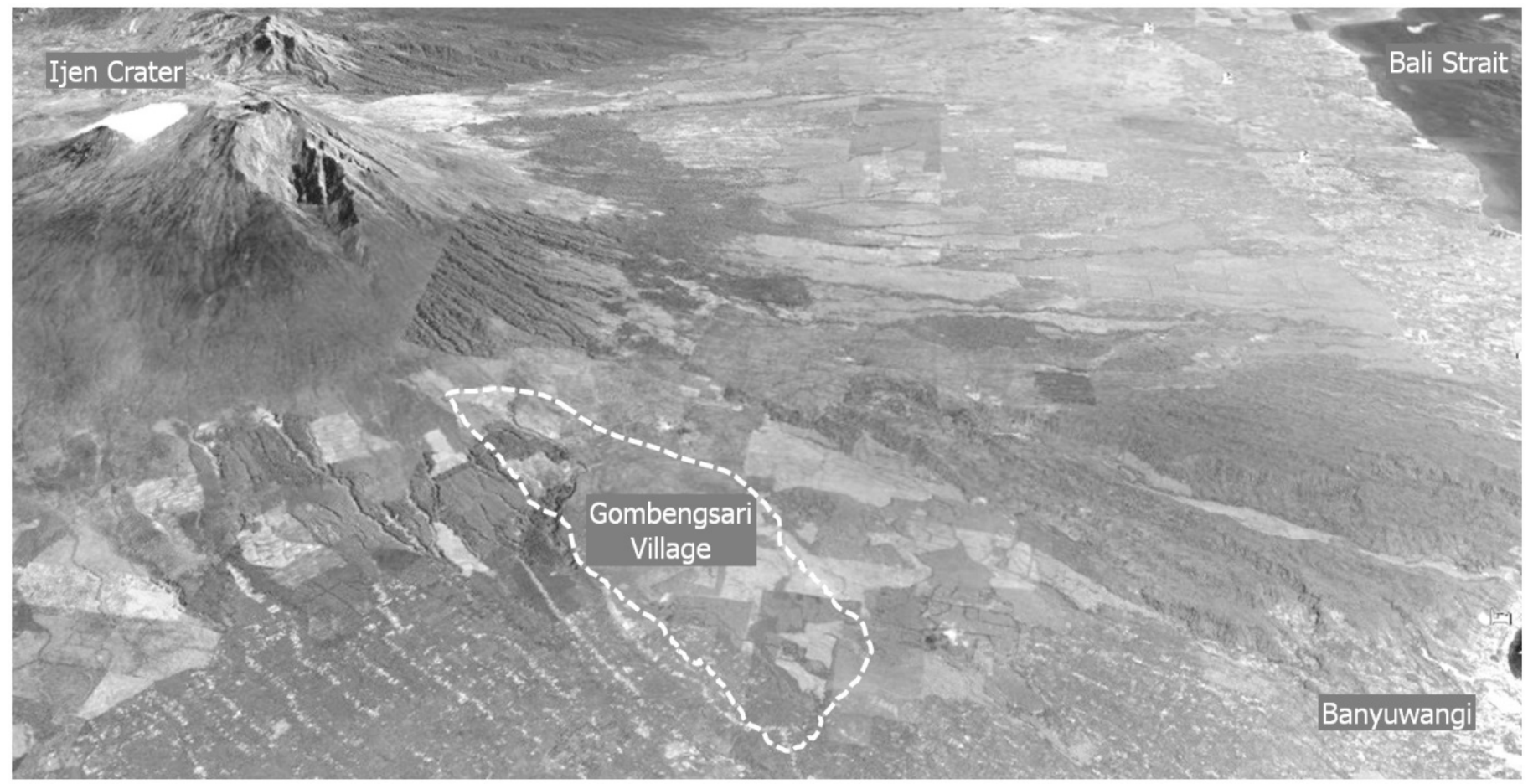

Figure 2. Gombengsari village setting. Source: Adopted from (Kelurahan Gombengsari, 2018).

Table 4. Tourism Products and Services in Gombengsari

\begin{tabular}{|c|c|c|}
\hline Tourism products/ objects/facilities & Attractions & Managed by \\
\hline Coffee Cafe (7 cafes) & $\begin{array}{l}\text { Education: agrotourism, getting to know coffee, } \\
\text { roasting, grinding, serving coffee }\end{array}$ & Individual \\
\hline Etawa Goat (750 households) & Education: milking etawa goats & Individual \\
\hline Asmoro hilltop & $\begin{array}{l}\text { Nature tourism, point of view to the Bali strait, hills } \\
\text { and valleys }\end{array}$ & $\begin{array}{l}\text { LMDH Kemuning Asri } \\
\text { (forest village community } \\
\text { institutions) }\end{array}$ \\
\hline $\begin{array}{l}\text { Sumber Gedor water source, water res- } \\
\text { ervoir } 2,500 \mathrm{~m} 2 \text {, }\end{array}$ & $\begin{array}{l}\text { Nature tourism, built by the Dutch colonial in 1925, a } \\
\text { historical tour }\end{array}$ & $\begin{array}{l}\text { Water supply public } \\
\text { company }\end{array}$ \\
\hline Camping ground of Sumber Manis Suko & Campground & Suko Youth \\
\hline Pengantin Waterfall & Nature tourism, waterfalls & Kampung Anyar Youth \\
\hline Kaliklatak Tourism & $\begin{array}{l}\text { Enjoy coffee plantations, historical building tours } \\
\text { (buildings, factories, etc.), coffee and rubber education, } \\
\text { from planting to post-harvest }\end{array}$ & $\begin{array}{l}\text { Coffee plantation } \\
\text { company }\end{array}$ \\
\hline Homestay (10 houses) & Stay overnight, get to know the socio-cultural life & Individual \\
\hline Rent a motorcycle & Transportation services to tourist sites & Individual \\
\hline
\end{tabular}

(Kaliklatak coffee plantation) with an area of 1,013 ha is found (Table 4). Kaliklatak coffee plantations have been established since the Dutch colonial era and often get a visit by foreign tourists. People also work on livestock of goats, cows, and chickens. The typical goat Gombengsari is a type of Etawa, which produces milk in addition to consumed meat The number of Etawa goat farmers reaches around 750 households. Coffee and goat farming has shown rapid development to provide prosperity. These livelihoods make essential contributions to support agribusiness and ecotourism activities in rural area.

Since 2016, people have introduced coffee education for tourists, where before it was directly sold to middlemen. Robusta coffee education starts from coffee plantations (recognize the coffee farm, land management, pruning, branch care, rejuvenation, to harvest). Tourists are then invited to roast, pound until they brew coffee. Since then, Gombengsari tourism objects have been widely known and 
get visited by tourists. In certain cases, tourists are also introduced to education on milking Etawa goats

\section{Social Capital}

1. Ngadas village

The social capital of Ngadas villagers is expressed through the aspects of norms, trust, networking, and participation (Table 5). Ngadas people remain to maintain the traditional and cultural life of Tengger. The norms of the Tengger tradition are so powerful and govern the lives of the community in economic, social, and environmental aspects. Although some of them are not Buddhists, they firmly obey in following Tengger's norms. The harmonious life of the local people can be used as the most valuable asset in regional development (Sismudjito, Badaruddin, \& Lubis, 2013).

Tengger tribal people apply norms and values in their life, such as (i) setuhu, meaning obedience and respect for leadership and tradition, (ii) sayan, cooperative attitude, cooperation, mutual assistance, and (iii) prasaja, honest and wise manner (Sopanah, Sudarma, Ludigdo, \& Djamhuri, 2013). These values maintain the balance and harmony of life and become an essential capital for the use of natural services through tourism activities in the Tengger region. The manifestation of social ties implemented in various rituals or worship, which respects sacred places, and efforts to conserve nature, forests, mountains, and other nature.

In general, Ladewi (rural tourism institution) did not optimally show the role of the management of tourism services. Organizations should carry out the functions of planning, implementation, monitoring, and evaluation, as well as improvement efforts (Ministry of Tourism and Creative Economy, 2012). The monitoring and evaluation management mechanism does not work optimally. In fact, providing service satisfaction to tourists is more important. By doing so, they seek to improve the quality of ecotourism service as tourists desire. Innovative efforts to develop tourism products and services greatly help the sustainability of tourism businesses.2. Gombengsari village

The social capital of the people of Gombengsari in terms of norms, trust, networking, and participation aspects is presented in Table 6. The people come from Javanese and Madurese ethnic groups, dominated by devout Muslims. Traditions of congregated worship and praise feature the social life of Muslims, for example, tahlilan and sholawatan. The people have the habit of carrying out the slametan tradition as a thanksgiving for the blessings and gifts of God. The leadership of religious leaders is a role model in daily life, in addition to economic actors (tourism or agriculture) and village officials. The role of the figures becomes the glue of social life and the economic improvement of the village.

The economic life of the villagers has also been oriented towards a market economy. Agricultural land is mainly planted with the coffee plant. The coffee plant significantly has environmental conservation value, because it naturally provides soil covers against surface runoff. People also have

Table 5. Description of the social capital of Ngadas people in tourism services

\section{Social Capital}

Norm

Trust

Networking

\section{Collective participation}

\section{Description}

People are Javanese/Tenggerese ethnicity, adhering to Buddhist Javanese, observing the Tengger tradition (Kasodo, Karo, Entas, Unan-Unan, Kapat Ceremony, Petek'an, Kawatu Ceremony, etc.), respecting pedanyangan (place offerings), place of worship, and temple (mangku),

People develop harmony/togetherness, carry out local traditions and environmental conservation. During the Karo ceremony, apologize to the environment for feeling guilty of cutting wood, being humble, harmony with the environment

Violations are sanctioned by local rules, for example, cement fines, clean and repair the road.

The rules regarding environmental conservation follow the provisions of TNBTS and other laws

Trust is built based on Tengger norms and traditions, including faith in shaman (tribe figures). The people are more obedient/trusting the dukun than other figures

Trust has not yet fully emerged among tourism actors (and Ladewi tourism organizations or village tourism organizations) to develop the economy and provide services to tourists

Trust the village apparatus for carrying out local government policies and programs

Ladewi organization, for organizing 57 homestays, nine horse transporters, 53 jeeps (30 actively functions), and youth groups

Tourism office of regency provides socialization/training, standardization of services

TNBTS provides training and assistance, grants farmland to the people

NGO East Java Ecotourism Forum accompanies the development of trekking trait, cleanliness facilities People have communication with tourists, travel or jeep associations (coordinated or not by Ladewi. Ladewi functions less optimally

Village officials function as facilitators to empower and support the development of village tourism.

Planning: The people remain to continue traditional life, not fully involved in planning, and
Ladewi's provisions. Regular meetings discuss the issue of tourist distribution did not go well

Implementation: the people observe each other, imitate others who are successful to operate ecotourism services.

Monitoring and evaluation: It is not going well; improvement efforts are more of a suggestion, without any real activity to make changes.

People are very responsive to improve the quality of tourist services by tourist demand

There is innovation in developing tourism products and services, creating new tracks, photo spots, the milky way. 
Table 6. Description of the social capital of Gombengsari people in tourism services

\begin{tabular}{|c|c|}
\hline Social Capital & Description \\
\hline Norm & $\begin{array}{l}\text { People are ethnic Javanese Madura, adhering to Islam, practicing the tradition of tahlilan/sholawatan, } \\
\text { as a forum for communication and togetherness. The cooperation for action in the conservation of } \\
\text { water sources. People carry out the culture of safety for water, by means of cutting rice cone and eat- } \\
\text { ing together at the location of the water source) } \\
\text { People from generation to generation grow coffee, as such, plants/trees that protect the soil surface } \\
\text { against erosion } \\
\text { People do goat livestock, produce livestock manure, develop organic farming. Goat livestock bring } \\
\text { about blessings during Idul Qurban activities or newborn aqiqah sacrifice } \\
\text { Norms related to sanctions/rewards following formal rules/regulations by the government }\end{array}$ \\
\hline Trust & $\begin{array}{l}\text { Trust among people is built based on religious norms, including trust in religious leaders } \\
\text { Trust among people and tour operator (and tourism organizations) to develop the economy and pro- } \\
\text { vide services to tourists } \\
\text { Trust the village apparatus, carry out local government policies and programs, follow the calendar of } \\
\text { local government tourism programs }\end{array}$ \\
\hline Networking & $\begin{array}{l}\text { Organizations among business actors work well, for coordinating farmer groups, Pokdarwis (rural } \\
\text { tourism conscious group), LMDH Kemuning Asri, and youth groups } \\
\text { In collaboration with the district PDAM (Regional Water Supply Company) managing water sources } \\
\text { In partnership with Perhutani to manage Asmoro hilltop tourism } \\
\text { The tour manager has a network with tour operators in Banyuwangi } \\
\text { Village officials function as facilitators to empower and support the development of village tourism. } \\
\text { The role of Pokdarwis in managing and coordinating tourism actors is not yet optimal }\end{array}$ \\
\hline Collective participation & $\begin{array}{l}\text { Planning: initially (2015), only played by figures of coffee farmers accompanied by tourism actors and } \\
\text { NGOs from outside the village. Now, they take the initiative to plan and have the motivation to devel- } \\
\text { op businesses with intensive communication. } \\
\text { Implementation: Business actors independently execute their own decisions, deal with other actors } \\
\text { and tourists. The economy of coffee-based tourism, goats and natural attractions has developed } \\
\text { Monitoring and evaluation: In the business group, a mechanism for reviewing problems is developed, } \\
\text { and finding steps to improve the tourism business. Potential conflicts are identified to be compro- } \\
\text { mised. Spot visits are conducted by the manager to check the field. } \\
\text { Tourists also provide input/evaluations for improving tourism management } \\
\text { Innovation in developing tourism products and services, for example, through education. Tourists are } \\
\text { invited to join in roasting coffee, milking etawa goats. Historical tour of the Gedor water source is } \\
\text { being promoted }\end{array}$ \\
\hline
\end{tabular}

goat livestock, where the livestock manure is used for increasing soil nutrition of coffee plants. Trust is built well in socio-economic life in Gombengsari. Trust creates cooperation, mutual understanding, and sincerity to produce farm and tourism business performance, as is now happening. Trust occurs between people, the government, and tourists. Networks are shaped in tourism management, involving LMDH (Forest Village Community Institution), PDAM (water supply company), Perhutani (state-owned forest enterprises), Pokdarwis (rural tourism conscious group), a village youth, farmer groups, and tour operators. Social capital forms an institutional network based on trust and motivation to contribute to the benefits of managing a resource (Sunkar et al., 2016). Community participation in the tourism business in Gombengsari is very significant. Product development innovations go hand in hand with positive responses from tourists. Such conditions also stimulate the ability of entrepreneurial people. As such, the tourism business has provided welfare benefits and raised the village economy (Anup, Rijal, \& Sapkota, 2015). Participation would increases when people have positive perceptions and receive benefits from tourism activities (Masud, Aldakhil, Nassani, \& Azam, 2017; Shaffril et al., 2015). A study of Yusuf, (2020) in Yogyakarta states that local people who feel irritated by tourism activities will show a decrease in the number of people participating in tourism development.

\section{Social Capacity}

Social capacity shows the ability of components within the local community to manage ecotourism resources to produce benefits for local people sustainably. In this study, social capacity in the villages of Gombengsari and Ngadas is assessed from the ability to manage institution (I), social (S), economic (E), environmental (En) resources, and their effects on ecotourism (Et) (Figure 3). The results of the PLS analysis have taken into account the feasibility of the model, followed by a test of validity and reliability. The test results show that all latent variables meet the requirements (Table 7), including the data for each village. It means that the model can be implemented to explain the social capacity and its relationship with other latent variables. The test model also presents the relationship between latent variables, as presented in Table 8 . The combined data of the two villages show a significant relationship between variables ( $\mathrm{p}$-value $<0.05)$ shown by Institution (I) $\rightarrow$ Ecotourism (Et), Institution (I) $\rightarrow$ Social (S), Social (S) $\rightarrow$ Economic (E), and Social $(S) \rightarrow$ Environment (En). While the relationship that 
shows a p-value slightly above 0.05 , namely Environment $($ En) $\rightarrow$ Ecotourism (Et) (p-value 0.072), Institution (I) $\rightarrow$ Economic (E) (p-value 0.080) and Institution (I) $\rightarrow$ Environment (En) (p-value 0.072). The latter relationships can be considered to explain or support the phenomenon of social capacity. Table 8 also presents the relationships between variables for each village.

Furthermore, Table 8 presents the path coefficient of each village area. Thus, it provides a description of the differences between or confirmation of the results of the combined analysis. The relation of the Economic $(\mathrm{E}) \rightarrow$ Ecotourism $(\mathrm{Et})$ is more significant in Ngadas village, compared to Gombengsari village. It also does so on the relation of the Institution (I) $\rightarrow$ Environment (En). Conversely, the relationship of the Environment (En) $\rightarrow$ Ecotourism (Et) found more significant in Gombengsari than Ngadas. It also happens on the relation of the Institution (I) $\rightarrow$ Social (S) and the Social (S) $\rightarrow$ Environment (En).

Figure 3 also shows the crucial indicators of each latent variable, shown by the relatively high loading factor. Given the figure, the ecotourism variable is contributed by the income increase indicator (Et1). Social variables are mainly affected by communication (S1) and population participation in meetings (S4). Economic variables are more determined by collaborative management (E3) and involvement in ecotourism (E4). Meanwhile, Institutional variables are significantly contributed by leadership (I2) and organizational commitment (I5). Finally, environmental variables are determined by cleanliness (En2), protection from landslides (En3), and availability of trash bins (En4).

The results showed significant findings as follows. First, the villages of Ngadas and Gombengsari show the findings of a similar variable relationship. The relationship is the variable Social (S) $\rightarrow$ Economic (E) and Institution (I) $\rightarrow$ Economic (E). It is also confirmed in the combination of the two villages. Such circumstance shows that social and institutional factors in both areas function well and affect economic factors.

Second, the villages of Ngadas and Gombengsari show the findings of different variable relationships. In Ngadas village,

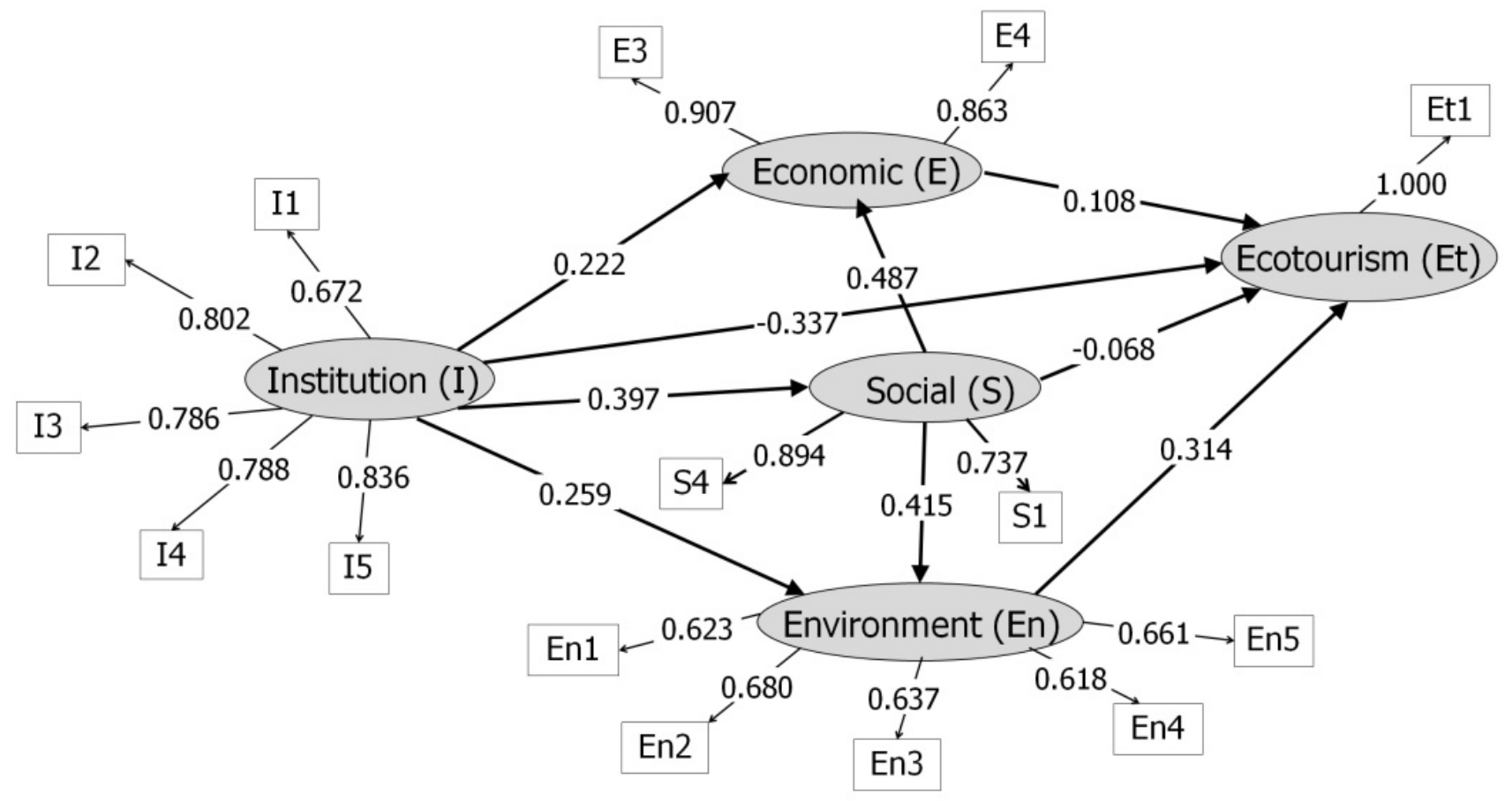

Figure 3. The Model of Variable Relations

Table 7. Result of Validity And Reliability Test

\begin{tabular}{|c|c|c|c|c|c|c|}
\hline \multirow[b]{2}{*}{ Latent variable } & \multicolumn{2}{|c|}{ Ngadas $(n=40)$} & \multicolumn{2}{|c|}{ Gombengsari $(n=50)$} & \multicolumn{2}{|c|}{ Total $(n=90)$} \\
\hline & $\begin{array}{c}\text { Average Vari- } \\
\text { ance Extract- } \\
\text { ed (AVE) }\end{array}$ & $\begin{array}{c}\text { Composite } \\
\text { Reliability (CR) }\end{array}$ & $\begin{array}{c}\text { Average Vari- } \\
\text { ance Extract- } \\
\text { ed (AVE) }\end{array}$ & $\begin{array}{c}\text { Composite } \\
\text { Reliability (CR) }\end{array}$ & $\begin{array}{c}\text { Average Vari- } \\
\text { ance Extract- } \\
\text { ed (AVE) }\end{array}$ & $\begin{array}{c}\text { Composite } \\
\text { Reliability (CR) }\end{array}$ \\
\hline Economic (E) & 0.558 & 0.834 & 0.774 & 0.872 & 0.784 & 0.879 \\
\hline Ecotourism (Et) & 0.840 & 0.913 & 0.675 & 0.806 & 1.000 & 1.000 \\
\hline Environment (En) & 0.574 & 0.842 & 0.479 & 0.783 & 0.415 & 0.780 \\
\hline Institution (I) & 0.769 & 0.909 & 0.622 & 0.891 & 0.607 & 0.885 \\
\hline Social (S) & 0.718 & 0.835 & 0.674 & 0.804 & 0.671 & 0.802 \\
\hline
\end{tabular}

The model is considered valid and reliable if AVE and CR exceed the ideal cut off values of 0.50 and 0.70 (Ghozali, 2006) 
Table 8. Relationships Between Latent Variables

\begin{tabular}{|c|c|c|c|c|c|c|}
\hline \multirow{2}{*}{ Latent variable } & \multicolumn{2}{|c|}{ Ngadas $(n=40)$} & \multicolumn{2}{|c|}{ Gombengsari $(n=50)$} & \multicolumn{2}{|c|}{ Total $(n=90)$} \\
\hline & Path coeficient & p-value & Path coeficient & p-value & Path coeficient & p-value \\
\hline$\overline{\text { Economic }(\mathrm{E}) \rightarrow \text { Ecotourism }(\mathrm{Et})}$ & 0.549 & 0.041 & -0.100 & 0.702 & 0.108 & 0.379 \\
\hline Environment $(\mathrm{En}) \rightarrow$ Ecotourism $(\mathrm{Et})$ & -0.026 & 0.865 & 0.503 & 0.036 & 0.314 & 0.072 \\
\hline Institution (I) $\rightarrow$ Economic (E) & 0.171 & 0.193 & 0.266 & 0.177 & 0.222 & 0.080 \\
\hline Institution (I) $\rightarrow$ Ecotourism (Et) & 0.089 & 0.613 & -0.141 & 0.603 & -0.337 & 0.020 \\
\hline Institution (I) $\rightarrow$ Environment (En) & 0.473 & 0.010 & 0.086 & 0.719 & 0.259 & 0.110 \\
\hline Institution (I) $\rightarrow$ Social (S) & -0.024 & 0.919 & 0.539 & 0.000 & 0.397 & 0.000 \\
\hline Social (S) $\rightarrow$ Economic (E) & 0.709 & 0.000 & 0.395 & 0.016 & 0.487 & 0.000 \\
\hline Social $(\mathrm{S}) \rightarrow$ Ecotourism $(\mathrm{Et})$ & 0.279 & 0.296 & -0.169 & 0.466 & -0.068 & 0.594 \\
\hline Social (S) $\rightarrow$ Environment (En) & 0.018 & 0.938 & 0.499 & 0.004 & 0.415 & 0.002 \\
\hline
\end{tabular}

${ }^{\text {a }}$ run by bootstrapping in PLS software

ecotourism development is constructed through Institution $(\mathrm{I}) \rightarrow$ Economic (E) $\rightarrow$ Ecotourism (Et) relations, while in Gombengsari, the corresponding relationship is Institution $(\mathrm{I}) \rightarrow$ Social $(\mathrm{S}) \rightarrow$ Environment $($ En) $\rightarrow$ Ecotourism $(\mathrm{Et})$. The relationship between variables that affect ecotourism is more complex or extended in the village of Gombengsari than in the village of Ngadas. As such, social and environmental aspects mediate the relationship between institutions and ecotourism. By doing so, the mediation in the village of Ngadas is played by economic factors. Another relationship found to be different between the two villages is in the relationship between institutions and the environment. In Ngadas village, the relationship was direct, but in Gombengsari village, the relationship was mediated by social aspects.

The above findings show that the relationship between variables in Gombengsari village is more complicated than Ngadas village. Social factors in the village of Gombengsari play a more optimal role, becoming a medium for communication and participation between people to carry out the regulatory function of environmental resources and provide benefits for village ecotourism management. This finding is consistent with the study of (Shaffril et al., 2015) and the discussion of social capital in the previous section.

The stock of social capital flows in the form of dynamic activities and interactions that reflect the relatively high social capacity in the village of Gombengsari. They use socioreligious forums to communicate and collaborate, then implement into coffee farming, Etawa goats cattle, conserving the environment, and networking to bring tourists to enjoy tourism activities in the village. Community life in the village of Gombengsari features an egalitarian society. Such phenomenon shows internal strength, through social ties, and transmits in real economic activities supporting ecotourism. Synergy is then reinforced by organizing an annual coffee festival that is included in the annual calendar of the Banyuwangi district government. Social capacity is increasingly enhanced by interactions outside the region (Mauerhofer, 2013).

Community social ties in the village of Ngadas are also resilient, proven to date able to adjust to the intense influence of tourism life. However, the social ties of Ngadas villagers play a limited role only for the needs of the Tengger tradition, including the regulation and conservation of cultural and environmental values. Social ties have not yet fully come into social life through education and participation in daily life to support tourism. It is relevant to the finding of a direct relationship between institutional and environmental variables. While in Gombengsari village, this relationship was facilitated by social factors.

Social ties are a tangible manifestation of social capital (Putnam, 2001), which results in empowerment and community participation in various lives (DeFilippis, 2001), especially the development of coffee-based ecotourism and Etawa goats in Gombengsari. According to Fukuyama, (2000), social capital is a set of norms that live in society, which is based on traditional values such as honesty, maintaining commitment, and its interactions that lead to cooperation and produce optimal performance. Resource management operates optimally due to the functioning of norms, partnership, trust, and social cohesiveness factors. The social capital seems to be much more significant in Gombengsari village than in Ngadas village. As such, the people of Gombengsari village will have the social capacity to live more independently and able to manage and solve problems through their social ties. Social capacity strengthens resilience and adaptability to deal with change (Amornsiriphong et al., 2012; Walker, Holling, Carpenter, \& Kinzig, 2004).

\section{Research Implications}

Research findings reveal three crucial implications in the development of ecotourism. First, the management of ecotourism development. As presented in Figure 3, some technical management implications are related to the variables studied. Strengthening the institutional aspects is aimed at improving the quality of leadership and organizational management, especially in institutions that manage ecotourism in two villages. According to Sunkar et al., (2016), social capital forms a local institution that sustains certain norms, which binds various interests (networks), builds trust and motivation for contributing the benefits of 
managing a resource. The establishment of a tourism institution in the village shows a high level of interest in managing tourism. However, this has not been able to be supported by the competence and managerial capabilities of human resources. Fostering rural tourism institutions is expected to enhance a more optimal allocation of resource management, develop cooperation with external parties, and develop tourism-based economic business services. These are the essential elements of entrepreneurship to increase community empowerment in rural tourism (Nugroho, Pramukanto, Negara, Purnomowati, \& Wulandari, 2016). Improving environmental aspects is mainly pointed to enhancing village cleanliness and preventing landslides from natural disasters. It is critical, especially in Ngadas village, because it has hilly physiography and a low cover crop on land. Gombengsari Village has a sheltered landscape because it applies the rules of agroforestry and integrated farming based on coffee and goats in the land around people's homes. Strengthening social aspects is aimed at increasing the participation of people in discussions and meetings in the village, as well as building communication quality (Shaffril et al., 2015). This effort is vital to increase knowledge, build mutual understanding, and trust to encourage cooperation and interaction. Strengthening economic aspects is led to widening participation and economic collaboration in managing tourism businesses. People are actively involved in tourism services and its supporting economy to receive welfare benefits.

Second, the methodology and approach to social capital and social capacity work well in the present research. The social capital approach using norm, trust, network, and participation variables has been widely used (Baksh et al., 2013; Sunkar et al., 2016). This approach reflects social ties as a stock of social capital (Mauerhofer, 2013). Meanwhile, the social capacity approach using institutional, social, economic, and environmental relations arrangements is a new point of view, although it is widely studied in the concept of sustainability (Mauerhofer, 2008; Volkmer \& Pedrozo, 2019). Mauerhofer, (2013) can clearly outline the concept of social capital and social capacity, and provides the foundation of this research methodology. Social capital and social capital are two different things; each representing stock/sink and flow. Both have a relationship with each other to support the

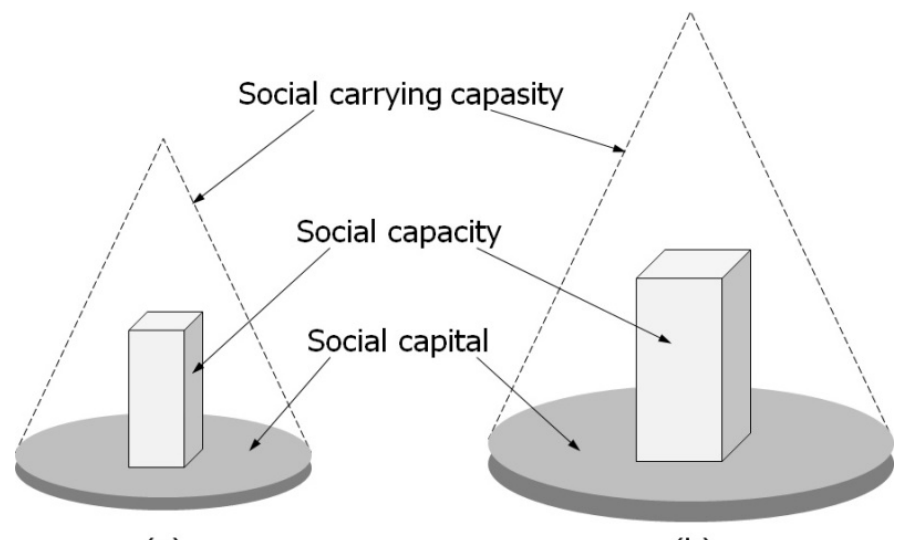

(a)

(b)

Figure 4. Dimensional Cone of Social Capital, Social Capacity, and Social Carrying Capacity in Ngadas (a) and Gombengsari (b) concept of sustainability. The present research combines these two things and produces valuable empirical findings to support the sustainability of the ecotourism services business. Previous studies have not been able to analyze in detail the social capital as the study by (Mauerhofer, 2013).

Third, the concepts of social capital and social capacity shape a framework for sustainability by including the idea of social carrying capacity. The concept of carrying capacity is much applied in ecology terminology, which has the general meaning of the ability of the environment to support the lives of humans and other living things within a particular spatial range. According to (Mauerhofer, 2013) social carrying capacity is the limit of growth or development of each hierarchical level of human or social integration within a certain spatial range, shaped by unilateral, multilateral, reflective, and/or interdependent processes within an individual and between individuals or groups of individuals within a certain time frame. It is similar to the definition of social capacity in the introduction section except adding 'the limit' in the beginning word.

The definition of social carrying capacity seems more challenging to understand than ecological carrying capacity, especially related to the sense of social limit. Why? Because social aspects of the community characterize different cultural traditions, attitudes, and behaviors, and this determines the sense of a certain social limit. However, the present research empirical evidence can at least open the view of the relationship between social capital, social capacity, social carrying capacity. The mapping of the research findings can be very valuable for the future research agenda to strengthen social capital studies as a stock/sink to support sustainability.Furthermore, the present study suggests the relationship in Figure 4 as adapted from Mauerhofer (2008), 2013). The figure is in the form of a three-dimensional cone, with the basis being social capital as stock/sink, beam-shaped flow is social capacity, and the inclined plane cone is social carrying capacity. As such, the research findings prove qualitatively that Gombengsari people show higher social capital, social capacity, and social carrying capacity than Ngadas village. The social carrying capacity of Gombengsari villagers is the area of the maximum limit of the possible social capacity reached. Characters such as an egalitarian society, interactions, networks, and the ability to manage resources, determine social carrying capacity.

\section{Conclusion}

The social capital for managing ecotourism services in Gombengsari is demonstrated by the performance of tourism institutions, networking capabilities, monitoring and evaluation, and innovation in tourism services. The management of ecotourism services in the village of Gombengsari is better than in the village of Ngadas. In contrast, the tourism service management organizations in Ngadas village do not work optimally.

Social capacity is related to the regulation of institutional, social, economic, and environmental resources. This arrangement is more complicated in the village of Gombengsari than in the village of Ngadas. Social and environmental aspects mediate the relationship between institutions and ecotourism. Meanwhile, the relationship to ecotourism in the village of Ngadas is facilitated by economic factors. Social factors in the village of Gombengsari can become a medium for communication and participation 
between people to carry out the regulatory function of environmental resources. The stock of social capital in the village of Gombengsari flows in the form of dynamic activities and interactions that reflect relatively high social capacity.

The implication of research management from an institutional aspect is to improve the quality of leadership and organizational management, especially in institutions that manage ecotourism. In the environmental aspect, the essential thing is to improve village cleanliness and prevent landslides. Strengthening social aspects is aimed at increasing people's participation in meetings and building communication quality. Strengthening economic aspects is through increased engagement and economic cooperation.

The research also has implications related to the conception of sustainability of ecotourism service management, by revealing the relationship between social capital, social capacity, and social carrying capacity. Adopting the study (Mauerhofer, 2008, 2013), the research findings prove qualitatively that Gombengsari villagers have much higher social capital, social capacity, and social carrying capacity than Ngadas village. It provides a more conceptual approach to strengthen the study of social capital as a stock/ sink and its relationship with sustainability.

This study acknowledges having limitations in the number of research respondents. The total number of respondents was 90 people, resulting in an inadequate possibility to make generalizations about social capital and social capacity. However, this study also complements indepth data exploration through intensive interviews with key persons to get background, participation, and opportunities for ecotourism development in the future. We believe that the present research is a genuine empirical study to find a conceptual framework regarding social capital and social capacity at tourist destinations in a rural area. Prior studies generally discussed remaining only about social capital and combining both without an adequate framework.

\section{Acknowledgment}

This research was funded by the Ministry of Research, Technology and Higher Education, Government of Indonesia, grant number 229/SP2H/LT/DRPM/2019.

\section{References}

Amornsiriphong, S., Piemyat, S., \& Charoenrat, O. (2012). Social capital: Foundation to strengthen the sufficiency economy communities. In Procedia Engineering (Vol. 32, pp. 1147-1151). Elsevier Ltd. https://doi.org/10.1016/j.proeng.2012.02.069

Anup, K. C., Rijal, K., \& Sapkota, R. P. (2015). Role of ecotourism in environmental conservation and socioeconomic development in Annapurna conservation area, Nepal. International Journal of Sustainable Development and World Ecology, 22(3), 251-258. https://doi.org/10.1080/13504509.2015.1005721

Baksh, R., Soemarno, S., Hakim, L., \& Nugroho, I. (2013). Social Capital in the Development of Ecotourism: A Case Study in Tambaksari Village Pasuruan Regency, East Java Province, Indonesia. J. Basic. Appl. Sci. Res, 3(3), 1-7. https:// doi.org/10.6084/m9.figshare.6265283

Bennett, N. J., \& Dearden, P. (2014). Why local people do not support conservation: Community perceptions of marine protected area livelihood impacts, governance and management in Thailand. Marine Policy, 44, 107-116. https:// doi.org/10.1016/j.marpol.2013.08.017

DeFilippis, J. (2001). The myth of social capital in community development. Housing Policy Debate, 12(4), 781-806. https:// doi.org/10.1080/10511482.2001.9521429

Desa Ngadas. (2018). RPJM (Middle-term Planning) Desa Ngadas Tahun 2018 - 2024. Malang: Desa Ngadas, Poncokusumo, Malang, INDONESIA.

Fukuyama, F. (2000). Social Capital and Civil Society (Working Papers). Washington, D.C., Amerika: International Monetary Fund (IMF). https://doi.org/10.5089/9781451849585.001

Fukuyama, F. (2001). Social capital, civil society and development. Third World Quarterly, 22(1), 7-20. https:// doi.org/10.1080/713701144

Ghozali, I. (2006). Aplikasi Analisis Multivariate dengan Program SPSS. Semarang, Indonesia: Publisher of Universitas Diponegoro. Retrieved from https://books.google.co.id/books? id=JdqJAQAACAAJ

Grootaert, C., Narayan, D., Jones, V. N., \& Woolcock, M. (2004). Measuring social capital: An integrated questionnaire. World Bank Working Paper. https://doi.org/10.1596/0-8213-5661-5

Handriana, T., \& Ambara, R. (2016). Responsible environmental behavior intention of travelers on ecotourism sites. Tourism and Hospitality Management, 22(2), 135-150. https:// doi.org/10.20867/thm.22.2.4

Hernanda, D. W., Mindarti, L. I., \& Riyanto, R. (2018). Community Empowerment Based on Good Tourism Governance in the Development of Tourism Destination (Case Study of Kawah Ijen Tourism Buffer Zone "Kampung Kopi" Gombengsari Village, Kalipuro District, Banyuwangi Regency). Journal of Indonesian Tourism and Development Studies, 6(2), 126-135. https://doi.org/10.21776/ub.jitode.2018.006.02.08

Jeyacheya, J., \& Hampton, M. P. (2020). Wishful thinking or wise policy? Theorising tourism-led inclusive growth: Supply chains and host communities. World Development, 131, 1-12. https:// doi.org/10.1016/j.worlddev.2020.104960

Kelurahan Gombengsari. (2018). Profil Kelurahan Gombengsari 2018. Banyuwangi: Kelurahan Gombengsari, Kec. Kalipuro, Kab Banyuwangi.

Kim, M., Xie, Y., \& Cirella, G. T. (2019). Sustainable transformative economy: Community-based ecotourism. Sustainability (Switzerland), 11(18), 1-15. https://doi.org/10.3390/su11184977

Lopez, J. C. C., \& Bhaktikul, K. (2018). Sustainable environment and tourism industry: An institutional policy analysis of northeastern Thailand. Polish Journal of Environmental Studies, 27(1), 31-37. https://doi.org/10.15244/pjoes/75198

Masud, M. M., Aldakhil, A. M., Nassani, A. A., \& Azam, M. N. (2017). Community-based ecotourism management for sustainable development of marine protected areas in Malaysia. Ocean and Coastal Management, (136), 104-112. https:// doi.org/10.1016/j.ocecoaman.2016.11.023

Mauerhofer, V. (2008). 3-D Sustainability: An approach for priority setting in situation of conflicting interests towards a Sustainable Development. Ecological Economics, 64(3), 496-506. https:// doi.org/10.1016/j.ecolecon.2007.09.011

Mauerhofer, V. (2013). Social capital, social capacity and social carrying capacity: Perspectives for the social basics within environmental sustainability. Futures, 53, 63-73. https:// doi.org/10.1016/j.futures.2013.08.006

Mendoza-Ramos, A., \& Zeppel, H. (2009). Indigenous Ecotourism in Preserving and Empowering Mayan Natural and Cultural Values at Palenque, Mexico. In Science and Stewardship to protect and sustain wilderness valuaes: Ninth World Wilderness Congress Symposium (pp. 27-33). USDA Forest Service Proceedings RMRS-P-64. Retrieved from https://www.fs.fed.us/ rm/pubs/rmrs_p064/rmrs_p064_027_033.pdf

Ministry of Tourism and Creative Economy. (2012). Handbook of Kelompok Sadar Wisata/Pokdarwis (Rural Tourism Conscious Group). Jakarta: Directorate General of Tourism Destination Development, Ministry of Tourism and Creative Economy, Government of Indonesia. Retrieved from http:// kemenpar.go.id/asset_admin/assets/uploads/media/old_all/1_ 
Pedoman Pokdarwis.pdf

Mursid, S., Suharno, S., \& Priatna, W. B. (2018). The Effect of Social Media on the Innovation Performance of the Small-Middle Scaled Enterprises of Agribusiness in Bogor Regency. Indonesian Journal of Business and Entrepreneurship, 4(1), 2236. https://doi.org/10.17358/ijbe.4.1.22

Nugroho, I., \& Negara, P. D. (2014). The Role of Leadership and Innovation in Ecotourism Services Activity in Candirejo Village, Borobudur, Central Java, Indonesia. World Academy of Science, Engineering and Technology, 0079, 1178-1182. https:// doi.org/10.5281/ZENODO.1087283

Nugroho, I., Negara, P. D., \& Yuniar, H. R. (2018). The Planning and The Development of The Ecotourism and Tourism Village In Indonesia: A Policy Review. Journal of Socioeconomics and Development, 1(1), 43-51. https://doi.org/10.31328/ jsed.vli1.532

Nugroho, I., Pramukanto, F. H., Negara, P. D., Purnomowati, W., \& Wulandari, W. (2016). Promoting the Rural Development through the Ecotourism Activities in Indonesia. American Journal of Tourism Management, 5(1), 9-18. https:// doi.org/10.6084/m9.figshare.6265169

Nunkoo, R., Ramkissoon, H., \& Gursoy, D. (2012). Public trust in tourism institutions. Annals of Tourism Research, 39(3), 15381564. https://doi.org/10.1016/j.annals.2012.04.004

Purnomo, P., In Oktaviani, A., \& Nugroho, I. (2018). The Sacred Site: The Conservation Based on The Local People in Tengger Community And Its Potential as Ecotourism Activities. Journal of Socioeconomics and Development, 1(1), 7-15. https:// doi.org/10.31328/jsed.v1i1.517

Purnomowati, W., Nugroho, I., \& Negara, P. D. (2012). Entrepreneurship Ability On Ecotourism Services Of Local People in Bromo Tengger Semeru National Park, Malang Regency, East Java, Indonesia . In 11th International Entrepreneurship Forum (11th IEF) Conference Entrepreneurship and Sustainability: From Lifestyles to Innovative Enterprises in Creative and Sustainable Environments, 3-6 September 2012 (pp. 458-473). Kuala Lumpur, Malaysia.: International Entrepreneurship Forum Conference. https://doi.org/10.6084/ m9.figshare.6267980

Putnam, R. (2001). Social capital: Measurement and consequences. Canadian Journal of Policy Research, 2(1), 41-51. https:// doi.org/10.1017/S1474746403001052

Rasid, A., Mustafa, M. Z., Suradin, A., \& Hassan, R. (2012). Community Capacity Building for Sustainable Tourism Development : Experience from Miso Walai Homestay. Business and Management Review, 2(5), 10-19. Retrieved from https:// nanopdf.com/download/community-capacity-building-forsustainable-tourism-development_pdf

Scheyvens, R. (1999). Ecotourism and the empowerment of local communities. Tourism Management, 20, 245-249. https:// doi.org/10.1016/S0261-5177(98)00069-7

Schwaninger, M. (2018). Systemic design for sustainability. Sustainability Science, 13(5), 1225-1234. https:// doi.org/10.1007/s11625-018-0538-5

Shaffril, M. H. A., Hamzah, A., Yassin, S. M., Samah, B. A., D’Silva, J. L., Tiraieyari, N., \& Muhammad, M. (2015). The Coastal Community Perception on the Socio-Economic Impacts of Agro-Tourism Activities in Coastal Villages in Malaysia. Asia Pacific Journal of Tourism Research, 20(3), 295-313. https:// doi.org/10.1080/10941665.2013.877048

Sismudjito, Badaruddin, \& Lubis, S. (2013). Harmonious Interaction Among Ethnical Communities In Regional Development. Indonesian Journal of Geography, 45(2), 149-156. https:// doi.org/10.22146/ijg.7128

Solár, J., Janiga, M., \& Markuljaková, K. (2016). The socioeconomic and environmental effects of sustainable development in the Eastern Carpathians, and protecting its environment. Polish Journal of Environmental Studies, 25(1), 291-300. https:// doi.org/10.15244/pjoes/60177

Sopanah, A., Sudarma, M., Ludigdo, U., \& Djamhuri, A. (2013).
Partisipasi Masyarakat Dalam Proses Penganggaran Daerah Berbasis Kearifan Lokal. In The 16th National Accounting Symposium, University of Sam Ratu Langi, Manado, Indonesia, September 25-28, 2013. Menado: IAI, Ikatan Akuntan Indonesia (Indonesia Accounting Assoc).

Sunkar, A., Meilani, R., Rahayuningsih, T., \& Muntasib, E. K. S. H. (2016). Social Capital: a Basis for Community Participation in Fostering Environmental Education and the Heritage Tourism Development of Cibalay Megalithic Site. Journal of Tourism, 3 (2), 120-129. Retrieved from http://ojs.unud.ac.id/index.php/ eot120

Volkmer, G., \& Pedrozo, E. Á. (2019). Agroecological farm analysis based on the 3D sustainability model approach. Agroforestry Systems, 93(3), 1001-1013. https://doi.org/10.1007/s10457-0180195-9

Walker, B., Holling, C. S., Carpenter, S. R., \& Kinzig, A. (2004). Resilience, adaptability and transformability in social-ecological systems. Ecology and Society, 9(2), 5-13. https:// doi.org/10.5751/ES-00650-090205

Wood, M. E. (2002). Ecotourism: Principles, Practices and Policies for Sustainability. Paris: UNEP Division of Technology, Industry and Economics. Retrieved from http://www.ucipfg.com/ Repositorio/MGTS/MGTS14/MGTSV-13/SEMANA1/ Ecotourism_1_EplerWood.pdf

Yolles, M. (2018a). Sustainability development: part 1 - from the cybernetic of cybernetics to the cybernetics of development. International Journal of Markets and Business Systems, 3(3), 238 -256. https://doi.org/10.1504/IJMABS.2018.093309

Yolles, M. (2018b). Sustainability development: part 2 - exploring the dimensions of sustainability development. International Journal of Markets and Business Systems, 3(3), 257-275. https:// doi.org/10.1504/ijmabs.2018.10014342

Yusuf, M. (2020). How Far Can Tourism Go? Residents' Attitudes toward Tourism Development in Yogyakarta City, Indonesia. Indonesian Journal of Geography, 52(2), 208-218. https:// doi.org/10.22146/ijg.38375 